\title{
Title: Pancreatic Morphology and Morphometric Analysis of Streptozotocin-induced Diabetes in Albino Rats Treated with n-hexane Extract of Leptadenia hastata Leaves.
}

\author{
Original Martha Orendu Oche Attah', Jacks, T. W', Garba, S.H.1and \\ Article Dibal, N.I
}

${ }^{1}$ Department of Human Anatomy, College of Medical Sciences, University of Maiduguri, P.M.B. 1069, Maiduguri, Borno State, Nigeria

${ }^{2}$ Department of Human Anatomy, Rivers State University, Port-Harcourt, Rivers State, Nigeria

\begin{abstract}
Background and Objectives: Diabetes mellitus is currently a major health problem and one of the most common endocrine diseases in the world especially in many developing countries. Treatment of diabetes have always included the administration of insulin and oral hypoglycemic agents in conjunction with lifestyle modifications. These treatments offer effective glycemic control however present limitations. Hence, traditional anti-diabetic plants have become popular in the management of diabetes mellitus.

Methodology: Diabetes mellitus was induced in 20 Wistar rats using a single injection of streptozotocin $(50 \mathrm{mg} / \mathrm{kg})$ administered intraperitonially. The rats were divided into four groups (3-6) of 5 rats each. Rats in group 3-6 received olive oil, $100 \mathrm{mg} / \mathrm{kg}$ of extract, $200 \mathrm{mg} / \mathrm{kg}$ of extract and insulin $(6 \mathrm{IU} / \mathrm{kg})$, respectively. 10 non-diabetic rats were grouped into 1 and 2. They received olive oil and $200 \mathrm{mg} / \mathrm{kg}$ of extract, respectively for 28 days. At the end of the study, the pancreas were removed and it was subjected tissue preparation.

Results: There was an improvement in the area of pancreatic islets in the groups treated with the extract and insulin. The islet cells in the diabetic group were atrophied with pyknotic and karyolitic cells. The mean number of pancreatic islets, pancreatic diameter and number of beta cells in the extract treated groups were significantly $(\mathrm{P}<0.05)$ increased when compared to the untreated diabetic rats.

Conclusion: $n$-haxane extract of Leptadenia hastata was found to have anti-diabetic and hypoglycemic properties and was also shown to improve the number and size of pancreatic islets in treated animals.
\end{abstract}

Key Words: Diabetes mellitus, leptadenia hastata, morphology, pancreas, streptozotocin.

Revised: 28 January 2019, Accepted: 21 February 2019

Corresponding Author: Oche Attah, Martha Orendu, PhD Candidate, Department of Human Anatomy, Faculty of Basic Medical Sciences, University of Maiduguri, Borno State, Tel.: +2348038135715, E-mail: marthaorendua@gmail.com.

ISSN: 1110-0559, Vol. , No.

\section{INTRODUCTION}

Diabetes mellitus (DM) at present is a major health problem and one of the most common endocrine diseases in the world ${ }^{[1]}$. At least 90 million people throughout the world suffer from diabetes mellitus ${ }^{[2]}$. Despite the great efforts that have been made and are being made in understanding and in the management of diabetes, the disorder and its debilitating conditions are continuing to increase unabated $^{[2,3]}$. Diabetes mellitus is a medical disorder which is often characterized by increased level of blood glucose which is a consequence of impaired or deficient insulin production, insulin resistance or both $^{[1-4]}$. It is also associated with long-term damage to various organs including the eyes, liver, kidneys, nerves, blood vessels and it may cause degenerative diseases in the central nervous system ${ }^{[3,4,5]}$, there is also danger of long time organ failure, blindness, amputation and premature death ${ }^{[4,5]}$. The management of diabetes is further complicated by the high cost of conventional drugs used in management of diabetes, the relatively high incidence of toxicity and side effects of these medications and the unavailability of orthodox drugs in many rural areas ${ }^{[5,6]}$. Considering the physiopathology of diabetes, a form of medication that would prevent beta cell and or pancreatic islet degeneration and stimulating the endogenous regeneration of islets will be in treatment of diabetes. There is also a need for medication for management of diabetes which has minimal side effect, is readily available and also affordable to many individuals who are suffering from the disorder. According to World Health Organization (WHO), approximately $80 \%$ of the world population currently use herbal medicines in treatment and management of many ailments but only a very little percentage of these herbs $(6 \%)$ have been studied for biological activity ${ }^{[5-7]}$. Hence, there 
is a need to increase the study of herbal medication which are beneficial in treatment of many ailment and for this reason, herbal medication and plants have been suggested as a rich, as yet unexplored source of potentially useful anti-diabetic drugs. However, only a few have been subjected to detailed scientific investigation especially as these plants have been used for many centuries for treating various ailment. Leptadenia hastata is one of these plants used locally as an herbal medication. It is a voluble herb with creeping latex stems, glabescent leaves, glomerulus and racemes flowers as well as follicle fruits. It is a palatable, non-domesticated vegetable found in wild throughout Africa ${ }^{[8]}$. Its documented usage in herbal medicine includes treatment against milk drying, sex-impotence, trypanosomosis, acute rhinopharyngitis and wounds ${ }^{[8,9]}$, it has been reported to have hypoglycemic and hypolipidaemic properties $^{[10]}$, cure prostate and rheumatism complaints and promote sexual potency ${ }^{[11]}$. A more informed research study on the effect of this herb on the histology of the pancreas would increase the store of available knowledge about this herb. As well as studying the histological function of the n-hexane extract of Leptadenia hastata, this research study also aims to study the effect of the extract on the morphology of the islets cells. Many researchers ${ }^{[12-16]}$ have studied the size, number and histo-architecture of the pancreatic islets as a parameter for testing an herbal preparation's effectiveness in restoring or promoting regeneration of pancreatic islet cells. An obvious increase in the weight of the pancreas, the size of the islets of Langerhans and improvement in the histo-architecture should be evident in the treated groups compared to untreated ones ${ }^{[7,12-13]}$. This study was aimed at determining the effect of Leptadenia hastata on the histology of pancreatic islets as well as observing its effect on islet size and shape in diabetic and non-diabetic rats.

\section{Methods}

\section{Chemicals and Reagents}

Streptozotocin (Bristol Scientific Company, Missouri, United States), soluble insulin injection (Novo Nordsick, Denmark) were commercially purchased. Sodium citrate granules (BDH chemicals, Poole, England) and citric acid granules (BDH chemicals, Poole, England) were dissolved in distilled water to make citrate buffer in which streptozotocin powder was dissolved in, Combostik11 Urinalysis strips (DFI Co, Ltd, Iran) was procured from a pharmacy and also from the University of Maiduguri Teaching Hospital, Maiduguri.

\section{Preparation of Plant Materials}

Collection, Identification and Storage of Plant Material

Leptadenia hastata was collected from a garden in the University of Maiduguri, Borno State, authenticated by a plant taxonomist, from the Department of Biological Sciences, Faculty of Science, University of Maiduguri. The leaves were harvested, washed and shade dried for a period of two weeks and then ground to powder using a mortar and pestle. The powder was sieved to obtain the fine powder, it was then labeled and stored for use.

\section{Extraction of Plant Material}

Maceration technique as described by ${ }^{[17]}$ was used for extraction in the present research work. The leaf powder weighing $500 \mathrm{~g}$ was dissolved in 3 liters of n-hexane in a 5 liter stoppered container. Maceration involved soaking the plant which is allowed to stand at room temperature for a period of 3 days at the minimum with periodic agitation. The process softened and disrupted the plant's cell wall to release the soluble phytochemicals. After 3 days, the mixture was filtered using Whatman's filter paper. The resulting $\mathrm{n}$-hexane filtrate was concentrated to dryness in-vacuo using an evaporator and the resulting powder was kept in an air-tight container and refrigerated.

\section{Experimental Induction of Diabetes in Rats}

Hyperglycemia was induced in overnight fasted albino Wistar rats by a single intra-peritoneal injection of $50 \mathrm{mg} / \mathrm{kg}$ streptozotocin (Bristol-Sigma, Bristol Scientific Company, Missouri, United States of America) dissolved in $0.1 \mathrm{M}$ ice-cold sodium citrate buffer, $(\mathrm{pH}=4.5)$, immediately before use in a volume of $1 \mathrm{ml} / \mathrm{kg}$ body weight as described by ${ }^{[18]}$. Hyperglycemia was confirmed by the elevated plasma glucose levels determined in tail blood sample using acu-check glucometer (Roche, Germany) after 72 hours of induction. Rats whose fasting blood glucose levels exceeded $250 \mathrm{mg} / \mathrm{dl}(13 \mathrm{mmol} / \mathrm{dl})$ after one week were considered as diabetic and used for the study ${ }^{[18-20]}$. Urinalysis was also carried out to confirm diabetes in all groups according to a method adopted by ${ }^{[21]}$.

\section{Animal Treatment}

A total of thirty rats (20 diabetic and 10 normal) of either sexes aged 68- months old and weighing about $120-160 \mathrm{~g}$. They were kept under standard environmental conditions and temperature. Water and industrialized dry pelletized food (ECWA feeds, Jos) were available ad libitum. The rats were divided into 6 groups of 5 animals each: Group 1 
consisted of non-diabetic rats who were administered olive oil. Group 2 were also non-diabetic and were administered $200 \mathrm{mg} / \mathrm{kg}$ of extract. Groups 3- 6 were diabetic groups: Group 3 received olive oil, Group 4 was treated with $100 \mathrm{mg} / \mathrm{kg}$ of extract and Group 5 received $200 \mathrm{mg} / \mathrm{kg}$ of extract. Group 6 rats were treated with insulin $(6 \mathrm{IU} / \mathrm{kg})$ as described by ${ }^{[4,8]}$. This treatment commenced after diabetes was confirmed and continued for a period of 28 days. Olive oil was used as vehicle to dissolve n-hexane extract of Leptadenia hastata which is insoluble in distilled water.

\section{Tissue Preparation}

The rats were sacrificed at the end of the experiment and the pancreas were recovered and its gross features were observed. The pancreas were then preserved in $10 \%$ formalin prior to further preparation and staining with heamatoxylin and eosin as well as modified aldehyde fuchsin to highlight alpha and beta islet cells ${ }^{[22-29]}$. The nuclei of alpha cells appear bluish with large, pink staining cytoplasm, whereas the smaller beta cells had black nuclei ${ }^{[28,29]}$. Other cell types are not easily distinguishable ${ }^{[29]}$.

\section{Morphometric Analysis of the Pancreas}

This was carried out with a linear scale-ocular micrometer and an area-measuring grid on the Amscope software. The ocular micrometer was calibrated with a $1 \mathrm{~mm}$ stage micrometer (Graticles Tonbridge, Kent, England). Thirty histological stained sections (five from each group) were used for the morphometric analysis. Islet outline and shape were examined at different magnifications in the nonserial pancreatic sections to estimate the number of islets in each section of the pancreas for each group, the area of the pancreatic islets and the number of beta cells of the pancreatic islets

The islet area was measured in each pancreatic section at $400 \mathrm{X}^{\prime}$ magnification using the area calibrated by the ocular micrometer to determine the difference in circumferential diameter in all groups. The number of islets and the area of pancreatic tissue were quantified in these sections at $400 \mathrm{X}$ magnification using the Amscope software.

The number of islets in the slides examined were determined by the cumulative average of number of islets per microscopic slide. The b-cells were determined by direct counting method at a magnification of $400 \mathrm{X}$ and zoomed by $10 \%$ using the ocular grid on the Amscope software and the point counting method of ${ }^{[30]}$ and was used to estimate the numerical density of the beta cells as demonstrated by ${ }^{[12,13]}$

\section{Statistical Analysis}

Data was statistically analyzed using GraphPad InStat software (version 3.75) by using One-way Analysis of Variance (ANOVA) and expressed as mean \pm SEM and percentage followed by Bonferroni Multiple Comparisons Test. $\mathrm{p}<0.05$ was considered to be statistically significant.

\section{RESULTS}

\section{Histological Observations in the Pancreas}

The micrographs of the pancreas stained with $\mathrm{H}$ and $\mathrm{E}$ is shown as Figures $1 \mathrm{~A}-\mathrm{F}$. Figure 4.7A and $\mathrm{B}$ depicts non-diabetic pancreas which are both characterized by a cluster of islet cells and the exocrine pancreas surrounding the pancreatic islets. The islet appeared as pale spheroid masses with rich vascular supply. Each islet consists of numerous cells with centrally located spherical nuclei. Beta cells are the most abundant cells and occupy the core of the islets and contain numerous granules. Alpha were observed at the periphery of the islets. The diabetic groups (Figure $1 \mathrm{C}-\mathrm{F}$ ) had greatly reduced number of islet cells which are as a result of induced diabetes in these groups. The diabetic control group (Figure1 C) showed islet cells which were poorly differentiated. There was decreased islets cellularity which was characterized by severe atrophy of pancreatic islets and greatly reduced number of cells in the pancreatic islet. The pancreatic islets in this group appeared to have very fewer in number and the sizes of pancreatic islets were also greatly reduced in this group. There was an increase in the volume of islets and number of cells found in the islets in groups treated with $100 \mathrm{mg} / \mathrm{kg}$ and $200 \mathrm{mg} / \mathrm{kg}$ of the extract (Fig $1 \mathrm{D}$ and $\mathrm{E}$ ) and in the insulin-treated group (Figure $1 \mathrm{~F}$ ).

Figure $2 \mathrm{~A}-\mathrm{F}$ depicts the micrograph of pancreatic tissue stained with modified aldehyde stain to highlight alpha and beta pancreatic cells. The beta cells in the diabetic group were very few in number (Fig. 2C) and the islets were atrophied with pyknotic and karyolitic cells. In the groups that were treated with the extract and insulin, there was an increased number of islet cells as observed in Figures 2D-F.

Figures $3 \mathrm{~A}$ and $\mathrm{B}$ shows the micrographs of pancreatic tissue stained with heamatoxylin and eosin and modified aldehyde fuchsin stains, indicating alpha and beta cells.

The mean number of pancreatic islets, pancreatic diameter and number of beta cells in the extract treated groups (IV and V) were significantly $(\mathrm{P}<0.05)$ increased when compared to the untreated diabetic rats (group III). These parameters were also significantly $(\mathrm{P}<0.05)$ increased in the insulin treated rats (group VI) [Table 1] 

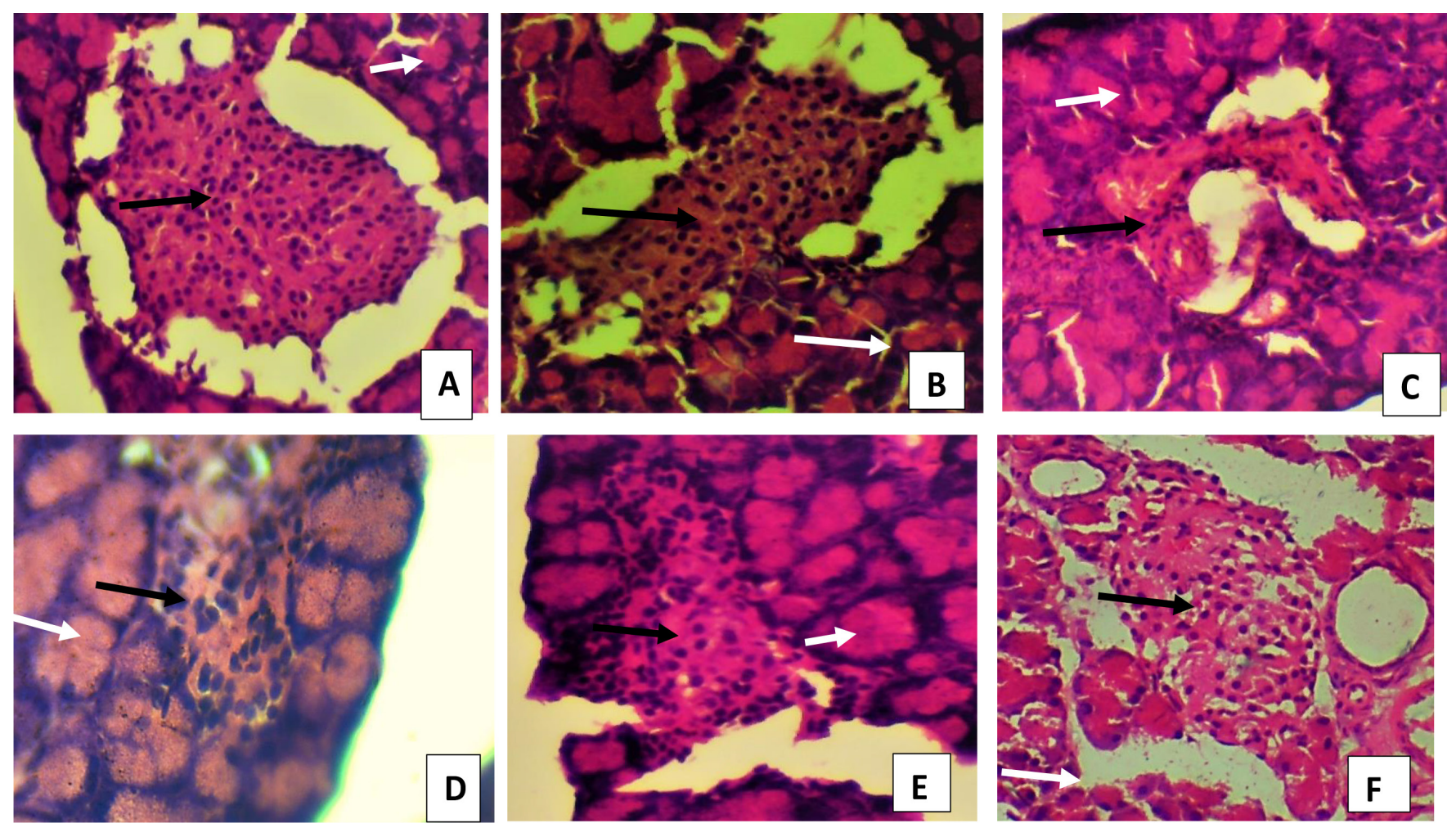

Fig. 1: The micrographs of pancreas in rats after 28 day oral toxicity study showing islet of Langerhans (black arrow) and pancreatic acinar cells (white arrow) Groups I (A), II (B), III (C), IV (D), V (E) and VI (F). H \& E X 100
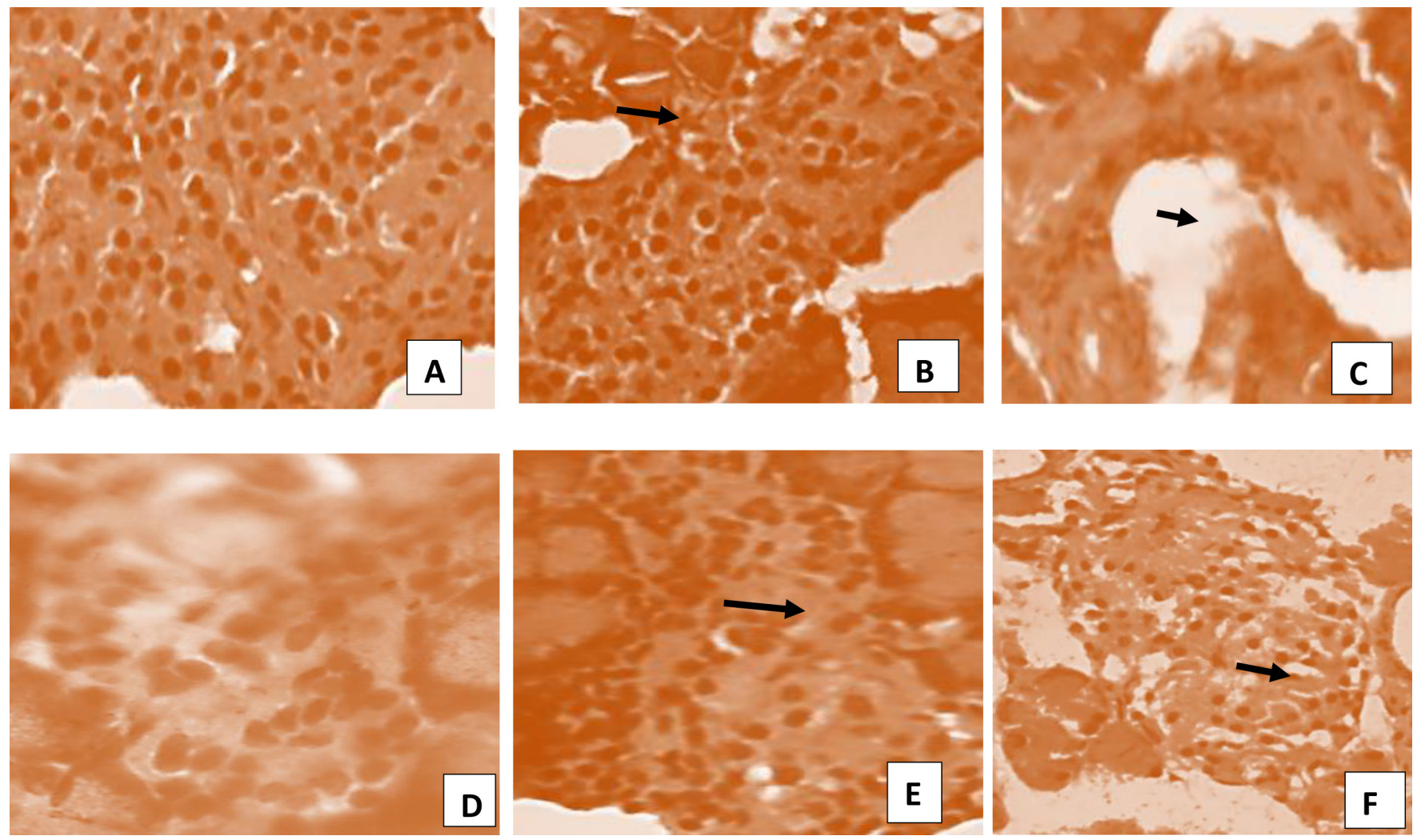

Fig. 2: Photomicrographs of pancreas in rats in all groups after the 28 day oral toxicity study showing beta cells in the pancreatic islets. Black arrow - Beta islet cell. Groups I (A), II (B), III (C), IV (D), V (E) and VI (F). Modified Aldehyde Fuschin X 200 


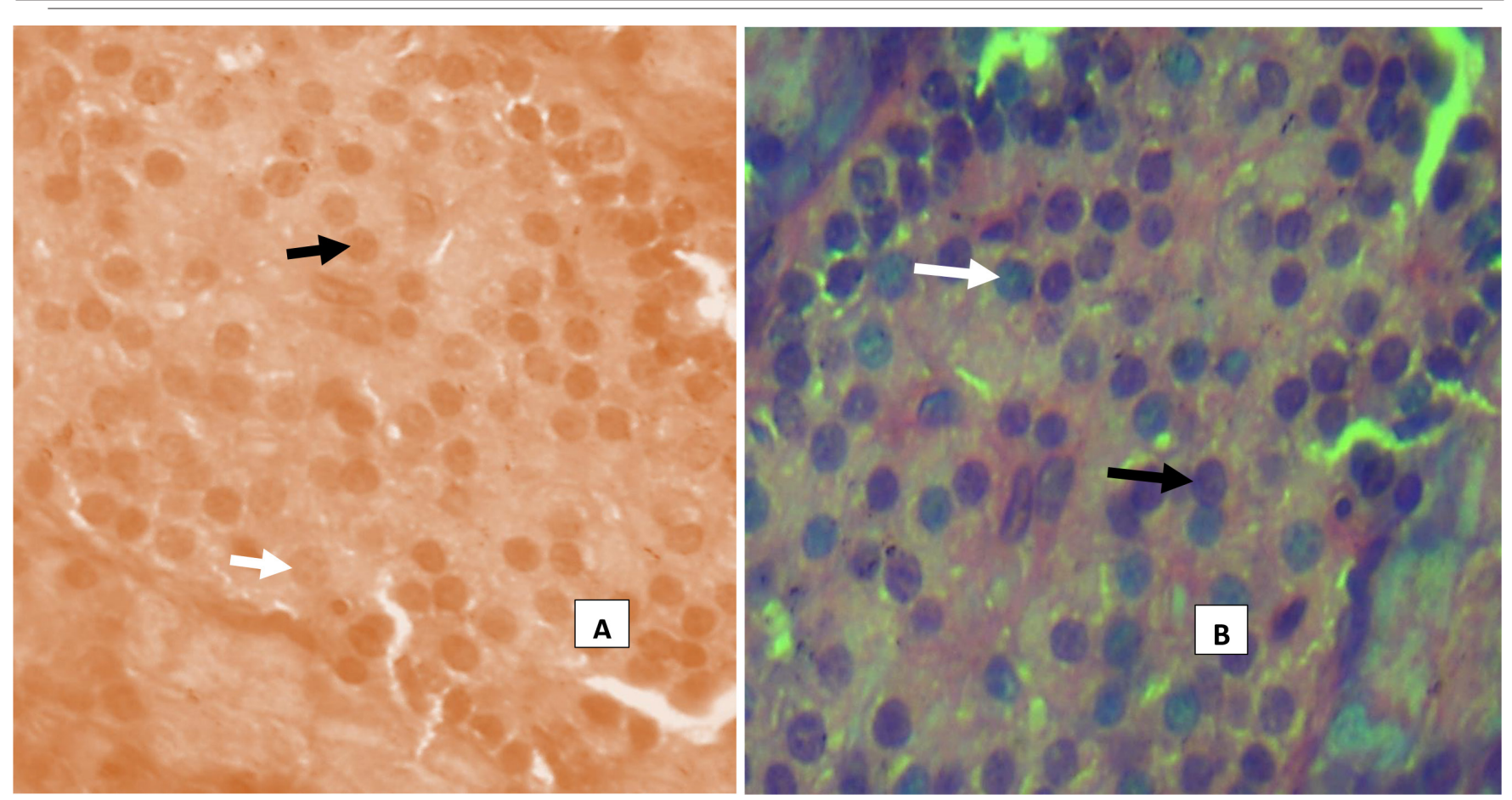

Fig. 3: Photomicrograph of pancreatic tissue from the control group stained with modified aldehyde fuchsin (A) and Heamtoxylin and Eosin (B) showing alpha cells (white arrows) and beta cells (black arrows) X400

Table 1: Morphometric analysis of the pancreas

\begin{tabular}{|c|c|c|c|c|}
\hline Groups & Treatment & Mean Number of Islets & Pancreatic Islet Area $\left(\mu \mathrm{m}^{2}\right)$ & Number of Beta Cells \\
\hline I & - & $26 \pm 5.0^{\mathrm{a}}$ & $192.2 \pm 7.2^{\mathrm{a}}$ & $248.2 \pm 7.5^{\mathrm{a}}$ \\
\hline II & Extract $(200 \mathrm{mg} / \mathrm{kg})$ & $23 \pm 2.0^{\mathrm{a}}$ & $145.2 \pm 10.8^{\mathrm{b}}$ & $233.3 \pm 4.4^{\mathrm{a}}$ \\
\hline III & - & $13 \pm 3.0^{\mathrm{c}}$ & $110.2 \pm 8.7^{\mathrm{c}}$ & $59.9 \pm 3.5^{b}$ \\
\hline IV & Extract $(100 \mathrm{mg} / \mathrm{kg})$ & $19 \pm 7.0^{\mathrm{a}}$ & $170.4 \pm 14.1^{\mathrm{a}}$ & $165.3 \pm 2.6^{\mathrm{c}}$ \\
\hline V & Extract $(200 \mathrm{mg} / \mathrm{kg})$ & $17 \pm 2.0^{\mathrm{b}}$ & $152.4 \pm 10.1^{b}$ & $125.5 \pm 7.1^{\mathrm{c}}$ \\
\hline VI & Insulin & $17 \pm 2.0^{\mathrm{b}}$ & $163.2 \pm 11.5^{b}$ & $169.3 \pm 1.6^{\mathrm{c}}$ \\
\hline
\end{tabular}

The values are expressed as mean \pm SEM. The values are expressed as mean \pm S.E.M expressed $(n=5)$. Values in the same column with different superscript are significantly different at $\mathrm{P}<0.05$. Values in the same column with same superscript are not significant.

\section{DISCUSSION}

The administration of the L. hastata had a hypoglycemic effect on the diabetic animals and it increased beta cell numbers, islet diameter in diabetic rats, reduced beta cell apoptosis in pancreatic islets, increased the number of insulin-positive beta cells in the islets, reduced islet degeneration and necrosis as well as increased proliferation of beta cells. The diabetic group that was not treated with either insulin or extract exhibited severe necrosis as well as an absence of islet cells which could be as a result of destruction of these cells by streptozotocin, however, in the treated groups, there was a marked improvement in the islet cells proving that the extract may had promoted islet beta cell survival, preserved islet mass or stimulated the regeneration of endogenous pancreatic beta cells. This corresponds to studies carried out by ${ }^{[7,31]}$. The exact mechanism by which the extract preserved the beta and other pancreatic islet cells was not studied in the present research study, however, phytochemical analysis of n-hexane extract of Leptadenia hastata revealed the presence of steroids, cardiac glycosides, terpenes and triterpenoids. The presence of these compounds were reported by ${ }^{[32,33]}$.

Terpenoids which belong to an important class of natural products and several terpenoids have been reported as anti-diabetic agents ${ }^{[34-39]}$.

The administration of $\mathrm{n}$-hexane extract Leptadenia hastata also significantly increased the mean area of the islets in streptozotocin-induced diabetic rats and the mean size of the islets of Langerhans as well as number of beta cells when compared with the diabetic untreated group. The data of the current work is in agreement with many researchers who reported that several other plant extracts succeeded in restoring the pancreatic weight in diabetic rats by repairing or regenerating pancreatic beta cells ${ }^{[14,16,40-41]}$. 
Leptadenia hastata has been locally used to treat diabetes and also for other various remedies. The extract administered to non-diabetic rats in group II had a significantly reduced islet area compared to the control group and this could be the result of the effect of the extract on healthy pancreatic tissue. In this group, there were many islets with smaller diameters and these could represent newly formed pancreatic islet cells. The extract may play a role in promoting the growth of new islets. ${ }^{[7,10,31]}$ researched the hypoglycemic effect of Leptadenia hastata and suggested the possible mechanism of the extract to include the stimulation of $\beta$-cells to replicate and/ or regenerate, subsequent release of insulin and activation of the insulin receptors. It may also be linked to the inhibition of the alpha-glucosidase activity ${ }^{[42]}$ discovered that the mean weight of several organs were increased comparatively as observed from 200 $\mathrm{mg} / \mathrm{kg}$ body weight through to $500 \mathrm{mg} / \mathrm{kg}$ body weight when compared with the control group after being administered with Leptadenia hastata extract and that suggested that the extract had a hypertrophic effect on several organs and suggested further studies in case of prolonged exposure to higher concentrations of the extract. However, ${ }^{[43]}$ suggested that Leptadenia hastata could be safe for oral consumption even at chronic administration. In the present study, administration of the n-hexane extract of Leptadenia hastata at a dosage of $100 \mathrm{mg} / \mathrm{kg}$ and $200 \mathrm{mg} / \mathrm{kg}$ in streptozotocin induced diabetes mellitus has been shown to have hypoglycemic effect as well as has been shown to increase the size and number of pancreatic islet cells hence, the extract may have regenerative properties on the pancreatic islet cells.

\section{Recommendations for Further Study}

The islet cells in the present study were highlighted with histological staining methods. For further study, immunochemistry should be used to highlight the islet cells and specifically demonstrate beta pancreatic cells.

\section{Ethical Considerations}

All the experimental procedures utilized were performed in accordance with the approval of the Institutional Animal Ethics Committee.

\section{CONFLICT OF INTERESTS}

The authors declare no conflict of interests.

\section{ACKNOWLEDGEMENTS}

The authors appreciate Professor T.W. Jacks, Dr Sani H. Garba and Dr S.T. Balogun who devoted so much time, energy, untiring effort and whose guidance as well as helpful advice has helped throughout the course of the research. Much gratitude goes to all staff of Human Anatomy department, Dr. J.V. Zirahei, Dr. D.S. Amaza Mr. N.I. Dibal and Mrs. H.B. Ishaya for the tireless effort and support given to me during the course of the work. I acknowledge the helpful advice and support of as well as technical support given by the staff Histology and Gross Anatomy lab, Department of Human Anatomy, Biochemistry and Pharmacognosy lab, all of the University of Maiduguri for their support and assistance during this research work.

\section{REFERENCES}

1. Réggami Y, Berredjem A, Cheloufi $\mathrm{H}$, Berredjem $\mathrm{M}$. and Bouzerna N, Antihyperglycemic and antidiabetic effects of Ethyl(S)-2-(1-cyclohexylsulfamide carbamoyloxy) propanoate in streptozotocininduced diabetic Wistar rats, European Journal of Pharmacology 2006, 779:122-130

2. Zaahkouk SAM, Rashid SZA and Mattar AF. Anti - diabetic properties of water and ethanolic extracts of Balanites aegyptiaca fruits flesh in senile diabetic rats. The Egyptian Journal of Hospital Medicine. 2003,10: 90 108.

3. Patel SB, Santani D, Shah MB and Patel VS. Antihyperglycemic and anti-hyperlipidemic effects of Bryonia laciniosa seed extract and its saponin fraction in streptozotocin-induced diabetes in rats. Journal of Young Pharmacists 2012,4:1716-.

4. Neto MCL, de Vasconcelosa CFB, Thijana VN, Caldasa GFR, Araújob AV, Costa-Silvac JH, Amorima ELC, Ferreirab F, de Oliveirad AFM and Wanderleya AG. Evaluation of antihyperglycaemic activity of Calotropis procera leaves extract on streptozotocininduced diabetes in Wistar rats. Brazillian Journal of Pharmacognosy, 23(2013): 913919

5. Smith YR and Adanlawo IG, Hypoglycaemic Effect of Saponin from the Root ff Garcinia Kola (Bitter Kola) on Alloxan-Induced Diabetic Rats, Journal of Drug Delivery \& Therapeutics; 2012, 2(6), 912-

6. Nadro MS and Samson FP. The effects of Balanite aegyptiaca kernel cake as supplement on alloxan-induced diabetes mellitus in rats, Journal of Applied Pharmaceutical Science. 2014, 4 (10), pp. 058061-, 
7. Khalil NSA, Abou-Elhamd AS, Wasfy, SIA, Ibtisam MH, ElMileegy, Hamed Y and Ageely M, Antidiabetic and Antioxidant Impacts of Desert Date (Balanites aegyptiaca) and Parsley (Petroselinum sativum) Aqueous Extracts: Lessons from Experimental Rats, Hindawi Publishing Corporation Journal of Diabetes Research. 2016:110-

8. Ukwuani, AN and Igbokwu, MO. In Vitro Anti-diabetic Effect of Leptadenia hastata Leaves Fractions. Biosciences Research in Today's World, 2015, 1(1): 4046-

9. Aliero A and Wara SH. Validating the Medicinal Potential of Leptadenia hastata, African Journal of Pharmacy and Pharmacology. 2009, 3(6):335338-.

10. Bello A, Aliero AA, Saidu Y and Muhammad Phytochemical Screening, Polyphenolic Content and Alpha-Glucosidase Inhibitory Potential of Leptadenia hastata (Pers.) Decne. Nigeria. Bayero Journal of Pure and Applied Sciences. 2011, 19(2): 181186-.

11. Abubakar S, Usman, AB, Ismaila IZ, Aruwa, G, Azizat SG, Ogbadu GH and Onyenekwe PC. Nutritional and Pharmacological Potentials of Leptadenia Hastata (pers.) Decne. Ethanolic Leaves Extract, Journal of Food and Nutrition Research. 2013, 2(1): 5155-.

12. Adeyemi DO., Komolafe OA, Adewole OS, Obuotor EM, Abiodun AA and Adenowo, TK. Histomorphological and morphometric studies of the pancreatic islet cells of diabetic rats treated with extracts of Annona muricata Folia Morphology 2010, 69(2):92100-

13. da Silva AT, Lemes RM., Oliveira CJF and Almeida AS, Data on morphometric Analysis of the pancreatic islets from $\mathrm{C} 57 \mathrm{BL} / 6$ and BALB/c mice, Data in Brief 8(2016):10941098.

14. Hosseini, A, Shafiee-Nick, R. and Ghorbani, A. (2015).Pancreatic beta cell protection and regeneration with phytotherapy. Brazilian Journal of Pharmaceutical Sciences 51(1), $116-$.

15. Ozdemir O, Akalin PP, Baspinar $\mathrm{N}$ and Hatipoglu F. Pathological Changes in the Acute Phase of Streptozotocin-Induced Diabetic Rats Bull Vet Inst Pulawy 2009, 53, 783790-.
16. Shanmugasundaram, E.R.B.; Rajeswari, G . ; Baskara N , K . ; Kumar, B .R.R. ; Shanmugasundaram, K.R.; Ahmath, B.K. Use of Gymnema sylvestre leaf extract in the control of blood glucose in insulin-dependent diabetes mellitus. J. Ethnopharmacol., v.30, p.2811990,294-.

17. Azwanida N.N. (2015). A Review on the Extraction Methods Used in Medicinal Plant: Principles, Strengths and Limitations, Medicinal and Aromatic Plants, 4(196):16- .

18. Etuk EU, Animals Models for Studying Diabetes Mellitus, Agriculture And Biology Journal of North America, 2010,1(2): 130134.

19. Furman, B.L. Streptozotocin-induced diabetic models in mice and rats. Curr. Protoc. Pharmacol. 2015. 70:5.47.15.47.20-. doi: 10.10020471141755/.ph0547s70

20. El Rabey, H.A., Al-Seeni M.N. and Bakhashwain A.S. The Antidiabetic Activity of Nigella sativa and Propolis on StreptozotocinInduced Diabetes and Diabetic Nephropathy in Male Rats, Hindawi Evidence-Based Complementary and Alternative Medicine Volume 2017, doi.org/10.11555439645/2017/

21. Houcine B, Rachid A, Rabah D, Farid L, Nabila $B$ and Boufeldja T, Effect of saponosides crude extract isolated from Citrullus Colocynthis (L.) seeds on blood glucose level in normal and streptozotocin induced diabetic rats, Journal of Medicinal Plants Research. 2011, 5(31):68646868-.

22. Scott H.R. (1952) Rapid Staining of Beta Cell Granules in Pancreatic Islets, Stain Technology, 27:5, 267268-, DOI: 10.310910520295209105089/

23. Sheehan, D.C. and Hrapchak, B. Theory and Practice of Histotechnology, Battelle Press, 1987.

24. Mowry R.W. Aldehyde Fuchsin Staining, Direct or After Oxidation: Problems and Remedies, with Special Reference to Human Pancreatic Beta Cells, Pituitaries and Elastic Fibers. Stain Technology, 2009, Vol 53:3, pp141154-

25. Lyon H. and Preto P. Aldehyde Fuchsin Staining of Pancreatic Beta Cells, 
Reproducible High Contrast Staining of Formalin-Fixed and Parrafin Embedded Material. The Histochemical Journal, 1980, Vol 12:1 pp97105-.

26. Winburn, W.B. "Light and Electron Microscopy of the Islets of Langerhans of the Saimiri Monkey Pancreas." (1963). LSU Historical Dissertations and Theses. 864.https://digitalcommons.lsu. edu/gradschool_disstheses/864

27. Halami NS (1962): Stain Technol., 27 pp 184 Carlton's histological techniques, Drury and Wallington, R.A.B.A (1967).

28. Abu-Amara, T.M.M. and Gebaly Z.M. Effect of Sitagliptin "a Dipeptidyl Peptidase-4 (DPP4) Inhibitor" on the Endocrine Part of the Pancreas in Experimentally induced Diabetes in Adult Albino Rat; A Light Microscopic and Biochemical Studies, The Egyptian Journal of Hospital Medicine (2012) Vol. 49; 933- 945

29. Cormack, H.D. (1993); Essential Histology (Originally Published as Introduction to Histology), J.B. Lippincott, Philadelphia. 282- 287, 322- 329.

30. Weibel ER, Practical methods for Biologic Morphometry. Vol. 1. Academic Press, London, 1978, pp. 101- 161.

31. Hosseini A, Shafiee-Nick R and Ghorbani A, .Pancreatic beta cell protection and regeneration with phytotherapy. Brazilian Journal of Pharmaceutical Sciences 2015, 51(1), 1- 16.

32. Mailafiya MM Phytochemical Studies and Effect of Methanol Leaf Extract of Leptadenia Hastata (Pers.) Decne (Asclepiadaceae) on Acetic Acid Induced Writhes in Mice and Venom of Echis Ocellatus, being a Thesis Submitted to the School of Postgraduate Studies Ahmadu Bello University, 2014, Zaria.

33. Chukwudi EI and Yusha'u M Phytochemical Screening and Brine Shrimp Lethality Assay of the Leaf Extracts of Cucurbita Maxima, Euphorbia Hirta, Leptadenia Hastata and Mitracarpus Scaber, International Journal of Current Research in Life Sciences. 2016, 5(5):579583-.

34. Tan MJ and Ye Y, Anti-Diabetic Activities of Triterpenoids Isolated from Bitter Melon Associated with Activation of the AMPK Pathway, Science Direct, 2008, 15(3):263273-
35. Burdi, D.K., Qureshi, S. and Ghangaro, A.B. (2014). An Overview of Available Hypoglycemic Triterpenoids and Saponins to Cure Diabetes Mellitus, Advancements in Life Sciences 1(3):119128-.

36. Castellano JM, Guida A, Delgado T, Rada M and Cayeuela JA, Biochemical Basis of the Antibiotic Activity of Oleanolic Acid and Related Pentacyclic Triterpenes, Diabetes. 2013,62(6):17911799-.

37. Mandal A,Das V, Ghosh P. and Ghosh S,. Antidiabetic Effect of Freiedelan Triterpenoids in Streptozotocin Induced Diabetic Rat, Nat Prod Commun, 2015, 10(10):16836-.

38. Nazaruk J. and Borzym-Kluczyk M. The Role of Triterpenes in the Management of Diabetes Mellitus and its complications, Phytochemical Reviews 2015,14:675-690

39. Putta S, Yarla NS, Surekha C, Aliev G, Divakara MB, Santosh MS, Ramu R Zameer F, Chintala R., Rao PV, Shiralgi Y and Dhananjaya BL. Therapeutic Potentials of Triterpenes in Diabetes and its Associated Complications, Current Topics in Medicinal Chemistry, 2016, 16(23): 253242-.

40. Bangar AV and Saralaya MG. "Antihyperglycaemic activity of ethanol extract and chloroform extract of Indigofera tinctoria leaves in Streptozotocin induced Diabetic mice (family- Papilionaceae)," Research Journal of Pharmaceutical, Biological and Chemical Sciences. 2011, 2(1):445-455.

41. Hemalatha $\mathrm{C}$, Dhamotharan R and Murugesan S. "Effect of soy bean lectin on streptozotocin induced diabetic rats," Asian Journal of Experimental Biological Sciences, 2011,2 (2):231-236.

42. Garba, A., Maurice, N.A., Maina, V.A., Baraya, Y.S., Owada, A.H., Sa'adatu, I., Gugong, V.T., Sada, A., Agang I. and Hambolu, S.E. (2013). Effect of Leptadenia hastata Leaf Extract on Embryo-Foetal Development in White Albino Rats. Greener Journal of Medical Sciences, 3(4): 121128-.

43. Bakodo, P.C., Nadro, M.S, Panuel, B. Effect of Leptadenia hastata Ethanolic Extract

44. in Wistar Rats, International Journal of Science and Research (IJSR) 2016, 5(1), 609612-. 